\title{
Kinerja Keuangan dan Pengungkapan Tanggungjawab Sosial
}

\author{
Andika Pramukti \\ Universitas Muslim \\ Indonesia \\ Makassar, Indonesia \\ andika.pramukti@umi.ac.id
}

\author{
Andika Prawira Buana \\ Universitas Muslim \\ Indonesia \\ Makassar, Indonesia \\ andika.prawira@umi.ac.id
}

\begin{abstract}
Abstrak
Penelitian ini bertujuan untuk mengetahui pengaruh Kinerja Keuangan terhadap Pengungkapan Corporate Social Responsibility (selanjutnya disingkat CSR) perusahaan Badan Usaha Milik Negara yang terdaftar di Bursa Efek Indonesia. Penelitian ini menggunakan metode asosiatif untuk mencari hubungan antara Kinerja Keuangan dan Pengungkapan CSR, sedangkan teknik pengambilan sampel yang digunakan adalah purposive sampling pada periode penelitian 2015-2018, sehingga diperoleh 40 laporan keberlanjutan perusahaan sebagai sampel penelitian. Hasil penelitian menunjukkan adanya hubungan kausalitas positif ROE $(0,211)$ dan ROA $(0,142)$ namun tidak signifikan ROE $(1,10)$ dan ROA $(0,71)$ antara Kinerja Keuangan dengan Pengungkapan CSR. Hasil ini mengindikasikan bahwa stakeholder lebih mengandalkan informasi keuangan dibandingkan informasi non-keuangan seperti Pengungkapan CSR dalam mengambil keputusan.
\end{abstract}

Kata Kunci : Pengungkapan CSR, ROA, ROE, BUMN

\section{Abstract}

This study aims to determine the effect of financial performance on the CSR Disclosure of stateowned companies listed on the Indonesia Stock Exchange. This study uses an associative method to find relationships between Financial Performance and CSR Disclosure, while the sampling technique used is purposive sampling in 2015-2018 period, so that 40 company sustaianability reports are obtained as research samples. Results showed a positive causality relationship ROE $(0,211)$ and ROA (0.142) but insignificant Roe $(1,10)$ and ROA $(0.71)$ between Financial Performance with CSR Disclosure. These results indicate that stakeholders rely more on financial information than non-financial information such as CSR disclosure in making decisions.

Keywords : CSR Disclosure, ROA, ROE, BUMN

\section{Pendahuluan}

Perusahaan memperoleh laba yang tinggi dan kelangsungan hidup perusahaan terjaga, diharapkan berimbas pada kesejahteraan masyarakat luas di luar perusahaan dan hal itu merupakan prestasi manajemen dalam mengelola perusahaannya (Shleifer \& Vishny, 1986). Melalui laba yang diperoleh tersebut perusahaan akan mampu memberikan dividen kepada pemegang saham dan meningkatkan pertumbuhan perusahaan. Laba menjadi salah satu tujuan dari perusahaan karena demi mempertahankan kelangsungan hidup perusahaan tersebut (going concern).

CSR merupakan suatu tanggungjawab perusahaan yang didasari pada tiga prinsip dasar yang dikenal dengan istilah triple bottom line yang terdiri dari profit, people dan planet (Pramukti et al, 2019). Corporate Social Responsibility dapat digunakan sebagai alat marketing baru bagi perusahaan bila itu dilaksanakan berkelanjutan (Pérez, 2015).

Ketidakmampuan perusahaan untuk 
mendapatkan manfaat dari aktivitas CSR memang tidak dapat dirasakan dalam jangka pendek, sehingga menimbulkan asumsi bahwa aktivitas CSR hanya sekedar pemborosan dan mengurangi keuntungan yang diperoleh oleh perusahaan. Begitu pula stakeholder dan shareholder yang hanya melihat perusahaan dalam jangka pendek saja sehingga tidak menjadikan CSR sebagai salah satu hal penting dalam pengambilan keputusan khususnya dalam hal investasi yang memiliki prioritas terhadap return dan lebih mengandalkan kinerja keuangan perusahaan sebagai dasar pengambila keputusan (Kustono \& Sayekti, 2017).

Suciwati et al. (2017); Bukhori \& Sopian (2017) menyatakan bahwa adanya hubungan yang positif dan signifikan antara CSR yang diungkapkan dengan kinerja keuangan yang diproksikan dengan ROA dan ROE. Namun beberapa penelitian menunjukkan hasil yang berbeda bahwa tidak adanya hubungan yang berpengaruh singnifikan antara CSR dan kinerja keuangan yang diproksi dengan ROE (Putra, 2016).

\section{Telaah Literatur dan Pengembangan Hipotesis}

\section{a) Teori Keagenan}

Jensen \& Meckling (1976) menjelaskan hubungan keagenan (agency relationship) terjadi ketika satu atau lebih individu yang disebut sebagai principal membayar/memanfaatkan individu atau organisasi lain, yang disebut sebagai agen, untuk melakukan sejumlah jasa dan mendelegasikan kewenangan untuk membuat keputusan kepada agen tersebut. Hubungan keagenan utama terjadi antara pemegang saham (principal) dengan manajer (agen). Kepentingan yang berbeda antara pemilik dan pengelola menyebabkan perbedaan tujuan yang akan mempengaruhi kemajuan suatu perusahaan (Ness \& Mirza, 1991).

b) Corporate Social Responsibility Disclosure

Wu \& Shen (2013) menyatakan bahwa Corporate Social Responsibility adalah komitmen perusahaan dalam memberikan kontribusi jangka panjang terhadap suatu issue tertentu di masyarakat atau lingkungan untuk dapat mencip- takan lingkungan yang lebih baik. Dalam penelitian ini mengidentifikasi hal-hal yang berkaitan dengan pelaporan sosial perusahaan berdasarkan standar GRI (www.globalreporting.org). Indikatorindikator yang terdapat di dalam GRI yang digunakan dalam penelitian yaitu:

a. Indikator Kinerja Ekonomi (economic performance indicator)

b. Indikator Kinerja Lingkungan (environment performance indicator)

c. Indikator Kinerja Tenaga Kerja (labor practices performance indicator)

d. Indikator Kinerja Hak Asasi Manusia (human rights performance indicator)

e. Indikator Kinerja Sosial (social performance indicator)

f. Indikator Kinerja Produk (product responsibility performance indicator)

Berdasarkan pedoman GRI G4 terdapat 91 item yang tersebar pada enam indicator kinerja di atas. Dengan indicator inilah informasi pengungkapan CSR pada laporan tahunan perusahaan diukur melalui pemberian skor.

c) Kinerja Keuangan

Kinerja keuangan menurut Isbanah (2015) merupakan prestasi kerja yang telah dicapai oleh perusahaan dalam suatu periode tertentu dan tertuang pada laporan keuangan perusahaan yang bersangkutan. Ada dua macam kinerja yang diukur dalam berbagai penelitian, yaitu kinerja operasi perusahaan dan kinerja pasar. Kinerja operasi perusahaan diukur dengan melihat kemampuan perusahaan yang tampak pada laporan keuangannya. Untuk mengukur kinerja operasi perusahaan biasanya digunakan rasio profitabilitas (Laksmitaningrum, 2013). Para pelaku bisnis dan pemerintah tentunya membutuhkan informasi tentang kondisi dan kinerja keuangan perusahaan dalam pengambilan keputusan ekonomi. Maka analisis laporan keuangan sangat dibutuhkan dalam hal ini, untuk memahami informasi laporan keuangan. Analisis kinerja keuangan yang dilakukan 3 bermanfaat untuk melakukan klasifikasi atau prediksi terhadap 
harga saham. Analisis rasio keuangan didasarkan pada data keuangan historis yang tujuan utamanya adalah memberi suatu indikasi kinerja perusahaan pada masa yang akan datang (Setiawan, 2016).

Penilaian kinerja keuangan perusahaan umumnya menggunakan analisis rasio, dan dalam penelitian ini jenis rasio yang digunakan antara lain adalah rasio profitabilitas salah satunya dengan menggunakan Return On Assets (ROA) dan Return On Equity (ROE). ROA adalah rasio yang digunakan oleh perusahaan guna mengukur profitabilitas pada tingkat pendapatan, asset, dan modal saham (Junaeni, 2017).

\section{d) Pengaruh Kinerja Keuangan terhadap Pengungkapan CSR}

Pengungkapan CSR dapat memberikan dampak yang positif untuk entitas dimana dengan melakukan program-program CSR perusahaan mampu memberikan kepercayaan masyarakat terhadap produk perusahaan sehingga reputasi perusahaan juga dapat meningkat di mata masyarakat. Melalui teori legitimasi, perusahaan yang melakukan Pengungkapan CSR lebih berperan dalam meningkatkan legitimasi yang akan berpengaruh kepada sikap konsumen terhadap produk perusahaan (Ioannidou et al., 2014). Hasil penelitian tersebut menjelaskan bahwa terdapat hubungan positif dan secara signifikan antara Pengungkapan CSR terhadap profitabilitas perusahaan.

Pengungkapan CSR mampu meningkatkan kinerja keuangan yang dilihat pada rasio ROA ataupun ROE karena kuatnya legitimasi yang mereka terima dari programprogram yang dijalankan oleh perusahaan, kemampuan CSR yang menciptakan reputasi yang baik di sekitar perusahaan ternyata juga memberikan kepercayaan pada shareholder untuk tetap berinvestasi di perusahaan tersebut (Masyitah, 2017). Hal tersebut juga telah dibuktikan McGuire et al. (1988) bahwa pengungkapan CSR dengan signifikan dapat mempengaruhi kinerja keuangan suatu entitas. Berdasarkan latar belakang, teori, dan hubungan antara kedua variabel penelitian yang terbentuk sebelumnya, berikut kerangka konsep yang terbentuk:

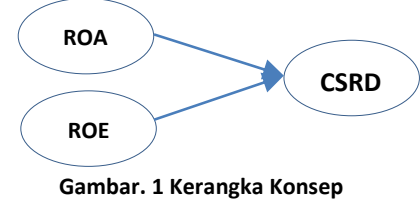

\section{Metodologi}

Penelitian ini menggunakan regresi linier sederhana yang bersifat deskriptif dan asosiatif guna menjelaskan hubungan antar variabel yang diteliti Pengungkapan CSR dan Kinerja Keuangan yang diproxikan dengan ROA dan ROE. Jenis data yang digunakan adalah data kuantitatif berupa data keuangan dan non-keuangan pada perusahaan BUMN yang listing Bursa Efek Indonesia dengan periode pengamatan 2015-2018. Populasi penelitian ini sebanyak 20 perusahaan BUMN yang bersifat eksploratif yang terdaftar di Bursa Efek Indonesia dan sampel melalui metode purposive sampling sebanyak 10 perusahaan dengan total laporan keberlanjutan yang dianalisis sebanyak 40 laporan selama periode penelitian. Pengumpulan data dalam penelitian ini dilakukan dengan cara melakukan penelusuran laporan keberlanjutan perusahaan yang terpilih sebagai sampel yang diperoleh dari www.idx.co.id.

\section{Hasil}

Hasil deskriptif merupakan gambaran umum sampel yang digunakan dalam penelitian yang juga akan menunjang informasi maupun justifikasi dari pembahasan penelitian. Tabel. 1 mendeskripsikan masingmasing variabel yaitu CSR yang diproxykan dengan CSDI sebagai variabel dependen, kinerja keuangan yang diproxykan dengan ROA dan ROE sebagai variabel independen.

\begin{tabular}{|c|c|c|c|c|c|}
\hline \multicolumn{6}{|c|}{ Tabel. 1 Descriptive Statistics } \\
\hline & $\mathrm{N}$ & Minimum & Maximum & Mean & Std. Deviation \\
\hline ROE & 40 & 2.01 & 41.01 & 20.3112 & 9.33173 \\
\hline ROA & 40 & -8.82 . & 20.68 . & 4.2237 & 6.19254 \\
\hline CSRD & 40 & 30.77 . & 95.60. & 56.0073 & 14.30201 \\
\hline Valid $\mathrm{N}$ & 40 & & & & \\
\hline
\end{tabular}

Hasil deskriptif dan pengujian asumsi klasik yang dilakukan sebelumnya mengantarkan kita pada pengujian persamaan regresi linier sederhana yang akan dianalisis. Tabel. 2 dibawah menunjukkan hubungan dan 
kausalitas antara CSR dan ROA.

$$
\text { P }
$$

Persamaan: $\mathrm{Y}=-1.196+0.211+0.142$

Dengan melihat persamaan yang ada diatas, maka analisis regresi dapat disimpulkan sebagai berikut:

a) Nilai Konstanta sebesar -1.196 dimaknai bahwa jika ROE dan ROA dalam keadan konstan atau nilainya sama dengan nol (0), maka nilai Pengungkapan CSR adalah sebesar -1.196.

b) ROE dan ROA memiliki hubungan kausalitas yang positif terhadap Pengungkapan CSR.

Hasil pengujian diatas menunjukkan bahwa pengaruh ROE dan ROA terhadap Pengungkapan CSR adalah positif dan tidak signifikan. Secara jelas diketahui bahwa ROE berpengaruh positif sebesar 0.211 terhadap Pengungkapan CSR atau dapat diinterpretasikan bahwa koefisien regresi yang diproxykan dengan ROE ditingkatkan 1 satuan atau mengalami penambahan $1 \%$ maka akan menjadi pengungkit dari peningkatan Pengungkapan CSR sebesar 21\% dengan asumsi bahwa variable lainnya memiliki nilai yang konstan atau tetap. ROA berpengaruh positif sebesar 0.142 terhadap Pengungkapan CSR atau dapat diinterpretasikan bahwa koefisien regresi yang diproxykan dengan ROA ditingkatkan 1 satuan atau mengalami penambahan $1 \%$ maka akan menjadi pengungkit dari peningkatan Pengungkapan CSR sebesar 14\% dengan asumsi bahwa variable lainnya memiliki nilai yang konstan atau tetap

Selanjutnya untuk mengetahui keeratan hubungan antara variable digunakan koefisien determinasi. Hasil uji koefisien determinasi ditampilkan pada table. 3 dibawah ini:

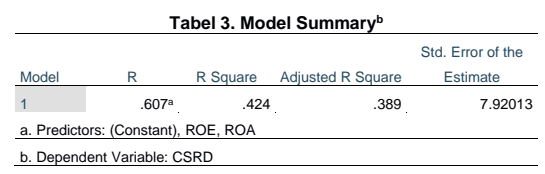

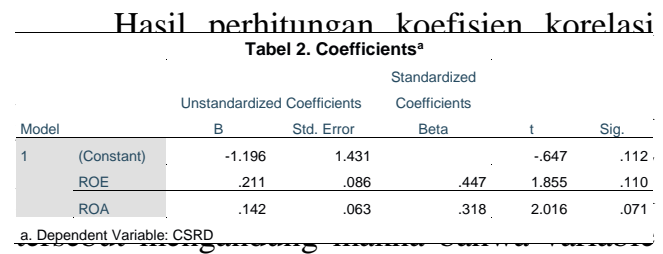
indipenden pada model yang tersaji dapat menjelaskan sebesar $42,4 \%$ terhadap fluktuatif variable terkait, sedangkan sisanya sebesar 57,6 ditentukan oleh variabel diluar model penelitian.

Pertanggungjawaban social perusahaan dapat diungkapkan di dalam laporan yang disebut Sustainability Reporting. CSR akan berdampak pada keberlanjutan apabila program yang dibuat oleh suatu perusahaan benar-benar merupakan komitmen bersama segenap unsur yang ada dalam perusahaan itu sendiri. Tentunya tanpa ada komitmen dan dukungan penuh antusias karyawan akan menjadikan program-program tersebut bagaikan program penebusan dosa dari pemegang saham belaka, dengan melibatkan karyawan secara intensif maka nilai dari program-program tersebut akan memberikan arti tersendiri yang sangat besar bagi perusahaan (Bukhori \& Sopian, 2017). Berdasarkan teori agensi, ditekankan pentingya pemilik principles dalam menyerahkan pengelolaan perusahaan kepada agent yang lebih mengerti dan memahami cara untuk menjalankan suatu usaha (Feng et al., 2017).

Hasil pengujian diketahui pengaruh Kinerja Keuangan terhadap Pengungkapan CSR pada Perusahaan BUMN yang terdaftar di BEI menunjukkan hasil koefisien sebesar 0,211 (ROE) dan 0,142 (ROA) dengan signifikansi sebesar 0,110 (ROE) dan 0,71 (ROA). Koefisien positif dan Nilai signifikansi yang lebih kecil dari 0,05 tersebut menandakan bahwa Kinerja Keuangan berpengaruh positif dan tidak signifikan terhadap Pengungkapan CSR. Hal ini menunjukkan bahwa investor tidak merespon atas pengungkapan CSR yang telah dilakukan oleh perusahaan. Akan tetapi semakin tinggi tingkat Kinerja Keuangan mengakibatkan pengaruh yang begitu rendah terhadap 
Pengungkapan CSR. Hal ini didukung oleh Bukhori \& Sopian (2017) bahwa pengguna laporan keuangan sudah cukup informasi dalam mengambil keputusan tanpa menggunakan pengungkapan CSR sebagai dasar pendukung keputusan.

\section{Simpulan}

Perusahaan eksplorasi BUMN yang terdaftar di Bursa Efek Indonesia sudah mengungkapkan aktivitas CSR mereka di dalam sebuah Laporan Keberlanjutan, namun meningkatnya kinerja keuangan perusahaan justru memberikan dampak pengungkapan CSR yang semakin menurn. Hasil penelitian yang menunjukkan rendahnya kemampuan variabel Kinerja Keuangan untuk mempengaruhi variabel Pengungkapan CSR terlihat pada nilai R-Square yang hanya sebesar 42,4\%. Hal ini diindikasikan bahwa stakeholder lebih mementingkan informasi keuangan dibandingkan dengan informasi non-keuangan seperti Pengungkapan CSR.

\section{DAFTAR PUSTAKA}

Bukhori, M. R. T., \& Sopian, D. (2017). PENGARUH PENGUNGKAPAN SUSTAINABILITY REPORT TERHADAP KINERJA KEUANGAN. Jurnal SIKAP (Sistem Informasi, Keuangan, Auditing Dan Perpajakan), 2(1), 35 .

https://doi.org/10.32897/jsikap.v2i1.62

Jensen, M. C., \& Meckling, W. H. (1976).

Theory of the firm: Managerial behavior, agency costs and ownership structure. Journal of Financial Economics, 3(4), 305-360. https://doi.org/10.1016/0304405X(76)90026-X

Junaeni, I. (2017). Pengaruh EVA, ROA, DER dan TATO Terhadap Harga Saham pada Perusahaan Makanan dan Minuman di BEI. Owner, 1(2), 32-47. Retrieved from https://owner.polgan.ac.id/index.php/o wner/article/view/33

Kustono, A. S., \& Sayekti, Y. (2017). EFFECT OF GOOD CORPORATE GOVERNANCE , CORPORATE SOCIAL RESPONSIBILITY
DISCLOSURE AND MANAGERIAL OWNERSHIP TO THE CORPORATE

VALUE WITH FINANCIAL PERFORMANCE AS INTERVENING VARIABLES : CASE ON INDONESIA STOCK EXCHANGE. International Journal of Social Science and Business, 1(Vol.1 (2) pp. 75-88), 75-88.

Ness, K. E., \& Mirza, A. M. (1991). Corporate social disclosure: A note on a test of agency theory. The British Accounting Review, 23(3), 211-217. https://doi.org/10.1016/08908389(91)90081-C

Pérez, A. (2015). Corporate reputation and CSR reporting to stakeholders. Corporate Communications: An International Journal, 20(1), 11-29. https://doi.org/10.1108/CCIJ-01-20140003

Pramukti, A., Haming, M., Nasaruddin, F., \& Chalid, L. (2019). Analysis Reporting Disclosure of Corporate Social Responsibility Disclosure of Manufacturing Companies. International Journal of Innovative Science and Research Technology (Vol. 4). Retrieved from www.ijisrt.com

Putra, A. S. (2016). PENGARUH CORPORATE SOCIAL RESPONSIBILITY TERHADAP PROFITABILITAS PERUSAHAAN (Studi Empiris pada Perusahaan Sektor Industri Barang Konsumsi yang Terdaftar di Bursa Efek Indonesia Tahun 2010-2013). Nominal, Barometer Riset Akuntansi Dan Manajemen, 4(2). https://doi.org/10.21831/nominal.v4i2.8 002

Shleifer, A., \& Vishny, R. W. (1986). Large Shareholders and Corporate Control. Journal of Political Economy, 94(3, Part 1), 461-488. https://doi.org/10.1086/261385

Suciwati, D. P., Pradnyan, D. P. A., \& Ardina, C. (2017). PENGARUH CORPORATE SOCIAL RESPONSIBILITY TERHADAP KINERJA KEUANGAN. Jurnal Bisnis Dan Kewirausahaan, 12(2 Juli), 104. https://doi.org/10.31940/jbk.v12i2 
juli.39 